\title{
How Women Are Depicted In Ads? A Content Analysis Study With Brazilian Advertisements
}

\author{
Claudia Rosa Acevedo, (E-mail: helenita@convex.com.br), Uninove, Brazil \\ Jouliana Jordan Nohara, Uninove, Brazil \\ Ana Laura Arruda, Uninove, Brazil \\ Helenita R. Da Silva Tamashiro, University Of Business Administration In Orlândia, Brazil \\ Thomas Brashear,University Of Massachusetts
}

\begin{abstract}
The main purpose of this paper was to examine female roles portrayed by advertising. More specifically, the question that motivated this research project was: What messages about women have been given to society through advertisement? Have these portrayals been changed during the past decades? The study consisted of a systematic content analysis of Brazilian commercials from 1973 to 2000. The population from which this sample was drawn consisted of Brazilian commercials which got an award in international and national festivals. A probabilistic sample procedure was employed. Ninety five pieces were selected. The categories and operational rules used in the study were developed based on previous research. This study has proposed that female images in advertising are depicted in three different ways: stereotyped, idealized and plural portrayals. Our results have revealed that some specific images have changed; however, they continued to be stereotyped and idealized.
\end{abstract}

\section{INTRODUCTION}

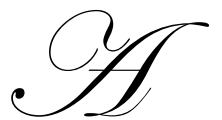

Dvertising Images Remain An Important Topic For Marketing And Advertising Literature Because Research Suggests That Visual Imagery Provided By Advertisements Has A Significant Effect On The Belief System Of A Given Society. Indeed, Advertising Produces And Reflects Values, Attitudes And Behaviors Of The Social Realm Where It Is Embedded. It Gives Meanings To Words And Symbols, Playing A Special Role In The Interpretation Frame Of The Current World (Kang, 1997). Actually, Advertising Molds And Mirrors Life And This Is Enough To Pledge Our Attention. Whereas, Advertising's Critics Have Generally Held That Mass Media Pictures May Well Be Selective And Biased To Forge Specific Ideas, This Fact Reinforce The Reason Why These Images Represents An Important Historical Record, As They Denounce How A Given Society Would Like To See Itself. (Belk; Pollay, 1985).

Research Related To Female Portrayals In Advertising Has Been The Focus Of Attention Of Many Academic Studies Because Mass Media Messages About Women Have Often Depicted Them In A Stereotypical Manner Such As: Women Are Irrational, Fragile, Not Intelligent, Submissive And Subservient To Men (Courtney; Lockeretz, 1971; Venkatesan; Losco, 1975; Belkaoui; Belkaoui, 1976; Goffman, 1979; Blackwood; 1983; Bretl; Cantor, 1988; Jolliffe, 1989; Luebke, 1989; Kang, 1997). In Addition, These Investigations Have Shown That These Portrayals Haven't Reflected Changes In Female Roles In Modern Societies. Indeed, Mass Media Has Concocted Women's Image Mainly As Sex Object, Wife And Mother Whose Primary Goal In Life Is To Look Beautiful For Men (Kosimar, 1971).

It Is In This Context That The Main Purpose Of This Investigation Is To Examine Female Roles Portrayed By Advertising. More Specifically, The Questions That Motivated This Research Were: 1) What Messages About 
Women Have Been Shown To Society Through Advertisements? 2) Have These Portrayals Been Changed During The Past Decades?

Whereas Marketing Scientific Community In Other Countries Has Been Examining This Topic Since The Seventies (Courtney; Lockeretz, 1971; Venkatesan; Losco, 1975; Belkaoui; Belkaoui, 1976; Goffman, 1979) Very Few Academic Articles Published In The Main Brazilian Academic Journals And Proceedings In Marketing Have Addressed This Subject Matter. This Void Should Be Fulfilled Because Advertising Portrayals Have Important Social Influences. Indeed, Studies Have Revealed That Stereotyped Portrayals Of Women Produce Negative Feelings In Female Viewers, As Low Self-Esteem, Depression And Anxiety (Martin; Kennedy, 1993; Stice; Shaw, 1994; Stephens, Hill, Hanson, 1994, Acevedo Et All, 2004). Hence, Studies In The Area Not Only Would Widen The Research Contribution Undertaken In Brazilian Context To Advertising Literature, But Also To Contribute To The Society To Whom These Images Are Imposed.

This article is organized in six parts. The first part is the introduction. In the second we present a literature review. In the third section we describe the methodology adopted. Subsequently, we present the results and discuss them taking into account previous research. Finally, the conclusion contains the implications of our results, the limitations of the study and suggestions for further research.

\section{LITERATURE REVIEW}

The literature review of this paper is composed mainly by previous research specifically related to female portrayals in advertising. However, as mass media reflects the society where it is embedded, we have included in this section a brief review of Gilberto Freyre (2003) description about female roles in Brazilian society in the XVIII and XIX centuries. As Freyre's research is considered to be a sociological, historical and anthropological masterpiece about Brazilian society, its analysis of female positions in that period seems to be the foundation to understand messages about women that advertising has been shown to this society.

\section{Advertising Images}

There Has Been A Stream Of Advertising Research That Has Focused On The Characteristics Of Female Imagery In Publicity. One Of The Most Important Investigations Related To This Subject Is Goffman's (1979) Study. The Objective Of His Investigation Was To Analyze Patterns Of Gender Roles In Advertising. The Author Analyzed Nearly 400 Print Advertisements And Concluded That "Women Are Weakened By Advertising Portrayals" (Kang, 1997: 6). Indeed, He Found Five Categories Which Pictured Women In A Depreciated Manner. They Were: Relative Size (Related To Social Weight), Feminine Touch (Women Tracing The Object), Function Ranking (Related To Hierarchy Of Functions), Ritualization Of Subordination (Women Is Depicted In Lowing Postures Which Express Subordination And Submissiveness) And Licensed Withdraw (Women Pictured As Removed Psychologically From The Situation).

Twelve Years Later, Kang (1997) Replicated Goffman'S Study And Proposed Two More Categories. There Were: Body Display (Meaning High Degree Of Nudity) And Independence. The Objective Of His Investigation Was To Develop A Comparative Study In Order To Analyze Which Female Roles Were Most Common In Magazine Advertisements In 1979 And In 1991. The Study Was Composed By A Random Sampling Of 504 Ads, 252 Pieces, As Well As In 1979 And In 1991, Which Were Collected From Women's Popular Magazines. Results Of Kang' Study Showed That Overall Portrayals Of Women Have Not Been Changed From 1979 To 1991. According To Kang (1979) “Advertisements Are Still Showing The Same Stereotyped Images Of Women”.

In Addition, Other Studies Undertaken In The Seventies Have Revealed That Female Portrayals In Publicity Are Often Cliché-Ridden, Such As Weak, Childish, Dependent, Domestic, Irrational And Subordinated To Men. Courtney And Lockeretz (1971), For Example, Concluded That Four Stereotypes Prevailed In Advertisements: 1) A Woman's Place Is In The Home; 2) Women Should Not Take Important Decisions Or Do Important Things; 3) Women Are Dependent And Need The Protection Of Men; 4) Men See Women As A Sexual Object And Not As A 
Human Being. Moreover, Venkatesan; Losco (1975) Found That Women Were Pictured As: 1) A Sexual Object, 2) Physically Beautiful, 3) As Sexy, 4) As High Living, 5) As Overachieving Housewife And 6) Dependent On Men.

Furthermore, Belkaoui; Belkaoui's results (1976) indicate that women were depicted primary: 1) in nonworking roles, 2) as low income earners, 3) in decorative roles and idle situations, 4) as having limited purchasing power. Another course of research examined the efficiency of modern women images in advertising. Jaffe; Berger (1994), for example confront two portrayals, the super woman and the equalitarian. In the first description "woman manages the demands of both job and home with little help from anyone" (Jaffe; Berger, 1994 p. 32). In the second a woman and man are responsible for same duties.

Further, The Stream Of Research Related To Content Analysis Of Female Portrayals In Advertising Has Been Extended To Focus On Perceptions Towards Ad Images And Their Negative Social Effects. Acevedo Et All (2004), For Example, Have Investigated How Women Interpret Female Representations In Advertising. The Authors Interviewed 60 Brazilian Women And Concluded That Women Perceive Advertising Images As "Depreciated", "Idealized" And "Modern". Considering The Depreciated Images, Interviewees Reported That They Perceive That Mass Media Depict Women In Four Manners, That Are 1) "Women As Not Intelligent Or Irrational" 2) "WindowDisplay"; 3) "Body Display"; And 4) As "Housewives". The Other Perception Reported In The Study Is Connected To The Idea That Portrayals In Ads Are Idealized And Hence Very Far From Real World. The Interviewees Considered Two Dimensions Of Idealization In Advertising: 1) "Woman As Physically Perfect", Which Is, Always Young, Beautiful, Skinny And Always Tidy; 2) "Absence Of Features Of Brazilian Women", Which Is, The Absence Of "Mulatas", Black And Brown Skinned Women. In This Depiction Women Are Blond, Tall And Have White Skin. The Third Group Was That Publicity Represents Women In A Modern Way, That Is, Woman As 1) Independent From Man; And As 2) Super Woman - Being Able To Be Mother, Professional, And Wife Concomitantly (ACEVEDO Et All, 2004).

Another stream of investigation has analyzed the negative social effects (also known as "unintended consequences of advertising") of idealized images in media. Martin; Kennedy (1993), Richins (1991), Stice and Shaw (1994), Martin; Gentry, (1997) studies, for example, revealed a positive correlation between idealized portrayals in ads, self-image and self-esteem. In addition, Stephens, Hill; Hanson (1994) examined how attractive and skinny endorsers were associated to self-image dissatisfaction and to dieting diseases among women.

Not only have the idealistic portrayals of women been focused by research, but also any type of advertising images that present unrealistic elements have come under investigators close scrutiny. In his study, Everardo Rocha Guimarães, a Brazilian social Anthropologist, has concluded that advertising imagery presents a magic solution to consumer problems. His study has shown that publicity concocts "idealized narratives" which show "another life" and sell "magic solutions" (ROCHA, 1984:139). Furthermore, the author states that whereas pleasure is always depicted extensively in mass media, loneliness, sadness, uncomforting, diseases and exploitation seem never to prevail (ROCHA, 1984).

\section{Women Roles In Brazilian Patriarchal Regime}

According to Freyre (2003) women who lived in the patriarchal system in Brazil were confined to domestic realm. Their responsibilities were to be mother and to manage the house. Indeed, women were apart from domains as politics, education, public policies, science and literature which were controlled by men.

According to Freyre (2003), women physical body represented an important symbol of her function in society. She should be during adolescence, pale, slim and fragile. However, after marriage it was accepted that she would become fat, deformed into a "shapeless mass", as well as, developing larger hips. In this moment she would be the housekeeper and the mother of the patriarchal family. Hence, this specialization of the body was related to their roles in society. Indeed, woman was anything else than man's "fleshly puppet".

Freyre (2003) have stressed the idealization portrayal of female body by men. In this idealization woman had not only delicate feet, waist and hands, but also big breasts. According to the author, the idealization of women was a 
strong element of the narcissistic aspect of the patriarchal man. He dominated and "pretended to adore her in order to feel stronger" (FREIRE, 2003 p. 213). To sum up, Freyre (2003) states that in the patriarchal society women personified "fragility", "beauty" and the "domestic realm". They were restrained to "artificial situations" in order to provide pleasure to male. Finally, the author stated that Brazilian society has overcome race prejudices much easily than gender discrimination. In this way, according to the author, women's inferiority was stronger than racism in Brazil.

\section{CONCEPTUAL FRAMEWORK}

We propose that images in advertising can be organized in three different groups: stereotyped, idealized and plural portrayals. These three labels are mentioned by the literature related to female portrayals in advertising. In addition, the majority of the categories and their operational definitions come from previous research, mainly from Goffman (1979). Nevertheless, they also come from Kang (1997), Courtney; Lockeretz (1971) Venkatesan; Losco (1975), Belkaoui; Belkaoui's (1976), Jaffe; Berger (1994) and Acevedo et all (2004) studies, as it is explained in the methodology part of the article. However, some few categories were developed in a pre-test of the present investigation. Table1 below presents these three groups.

Table 1

\begin{tabular}{|l|l|l|}
\hline Stereotyped portrayals & Idealized portrayals & Plural portrayals \\
\hline Feminine touch & Physically perfect & Independence \\
\hline Function ranking & Caucasian ethnic characteristics & Home and family tasks equity \\
\hline Ritualization of subordination & & Not Caucasian ethnic characteristics \\
\hline Licensed withdrawal & & Function equity \\
\hline Body-Revealing clothes or Nudity & & Rational \\
\hline Dependent & & $\begin{array}{l}\text { Women in a prestigious or professional } \\
\text { or high income earner }\end{array}$ \\
\hline Housewife & & \\
\hline Decorative role & & \\
\hline Women as physically beautiful & & \\
\hline Women as shallow & & \\
\hline Irrational & & \\
\hline Window display & & \\
\hline An object of ridicule & & \\
\hline Women as low income earners & & \\
\hline Super woman & & \\
\hline
\end{tabular}

\section{METHODOLOGY}

This Study Consists Of A Systematic Content Analysis Of The Role Portrayed By Women In Brazilian Commercials During 1973 To 2000. According To Berelson (1952: 55) "Content Analysis Is A Research Technique For The Objective, Systematic And Quantitative Description Of The Manifest Content Of Communication". Kassarjian (1977) Defines It As Scientific, Objective, Systematic, Quantitative And Generalizable Description Of Communications Content.

The Condition Of Objectivity Concerns With The Creation Of Analytical Categories. Specifically, The Objectivity Dimension Depends On Whether The Researcher Describes: 1) The Rules And Procedures; 2) Judge Training Process; 3) The Pre-Testing Of Measures; 4) Whether Judges Are Independent From The Author And Work Independently From Each Other; 5) Which Objectivity Index Was Applied (Kolbe; Burnett, 1991, Berelson, 1952; Karsarjian, 1977). On The Other Hand, Systematization Is Related To The Process Of Applying Pre Determined Rules To The Selection Of Communication Content. This Requisite Prevents The Study To Corroborate The Analyst's Assumption (Kolbe; Burnett, 1991, Hosty, 1969; Kassarjian, 1977, Berelson, 1952). According To Kassarjian (1977) Quantification Differentiates Content Analysis From Ordinary Critical Reading. The Author States That The 
Assessment Of The Degree Of Emphasis Or Omission Of Any Given Category Is What Content Analysis Is All About.

\section{Sample}

Advertising television was the unit of analysis for this study. In addition, the population from which this sample was drawn consisted of Brazilian commercials which got an award in international and national festivals from 1973 to 2000. These pieces were obtained from a project developed by a Brazilian organization named "Museu Virtual Memória da Propaganda" (Virtual museum of advertising memory).

Twenty seven years - from 1973 to 2000 - were chosen for the study. A two stage sample procedure was employed. First, those commercials which portrayed at least one woman were retained. In addition, repeated commercials were not selected for the sample. In a second stage all the remained commercials were enumerated and a probabilistic simple sample procedure was undertaken. Finally, ninety five pieces were selected. Using this sampling technique we intended to assure that the systematization criterion was followed.

\section{Coding Issues}

Objectivity specifies that the categories of analysis are defined quite precisely. In this way, the majority of the labels employed to nominate each category, their definitions and their measurements were based on previous research. However, some few categories were developed in the pre-testing of the present study. In addition, it is important to stress that the categories of this study were not independent or mutually exclusive. The labels, definitions and sources of each category are as follows:

- $\quad$ Feminine Touch: Women Are Portrayed Using Their Fingers And Hands To Trace The Outline Of An Object Or To Caress Its Surface. This Ritualistic Touching Is To Be Distinguished From The Utilitarian Touch That Grasps, Manipulates Or Holds. (Goffman, 1972; Kang, 1997)

- Function Ranking: When A Man And A Woman Participate In An Activity And Woman Takes A Subordinated Role. This Activity Could Happen Either Within An Occupational Situation Or Outside It (Goffman, 1972; Kang, 1997)

- $\quad$ Ritualization Of Subordination Through Physical Postures: Leaning Postures Can Be Read As An Acceptance Of Subordination And An Expression Of Submissiveness. (Goffman, 1972; Kang, 1997)

- $\quad$ Licensed Withdraw. The Woman Is Psychologically Removed From The Social Situation Which Surrounds Her. (Goffman, 1972; Kang, 1997)

- $\quad$ Body-Revealing Clothes Or Nudity: When The Woman Is Portrayed Showing A High Degree Of Nudity, As With Body-Revealing Clothes Or Completely Nude (Kang, 1997; Acevedo Et All 2004)

- $\quad$ Dependent - Women Are Portrayed As Dependent Financially Or Psychologically From Men. (Courtney; Lockeretz, 1971; Venkatesan; Losco, 1975)

- Housewife - In This Portrayal Woman Is Presented As A Full Time Housewife Who Doesn't Have A Professional Income. Taking Care Of The House And The Family Is The Center Activity Of Her Life. (Venkatesan; Losco, 1975; Belkaoui; Belkaoui, 1976; Acevedo Et All, 2004)

- Decorative Role - When There Is A Woman In The Advertising But She Doesn't Have Any Relation With The Product. She Has Only A Decorative Role In The Ad. (Belkaoui; Belkaoui, 1976; Venkatesan; Losco, 1975)

- Women As Physically Beautiful - Women Are Portrayed As Their Main Focus In Life Is To Become More Beautiful. (Venkatesan; Losco, 1975)

- Women As Shallow - Woman Is Concerned With Superficial Activities And Subjects. Her Main Focus Is To Spend Money, To Amuse Herself, To Buy And Consume Expensive Products Or To Engage In Luxurious Activities (Venkatesan; Losco, 1975)

- Irrational: Refers To The Image Of Woman Who Doesn’t Use Her Intelligence Or Doesn't Think. (Acevedo Et All, 2004)

- Window Display: Woman Is Portrayed As If She Were A "Hanger", A "Package" Or A "Shelf” Where The Product Is Exhibited To Be Sold. (Acevedo Et All, 2004) 
- $\quad$ An Object Of Ridicule: The Woman Is Portrayed As An Object Of Ridicule. She Is The Object Of Jokes, Malicious Comments Or She Behaves As A Ridiculous Comic Actress (Developed In The Pre-Test Of This Study)

- $\quad$ Women As Low Income Earners - Woman Is Represented In Positions Which Demand Low Or Intermediate Level Of Education, As Secretarial, Clerical Or Blue Collar Positions. They Are Never Depicted In Positions Which Demand High Level Of Education And Which Are Connected With High Status Or High Wages. (Belkaoui; Belkaoui, 1976)

- $\quad$ Super Woman: In This Image Woman Manages The Demands Of Job, Family And Home With Little Help From Anyone. In Despite Of Having A Job She Doesn't Share Family And Home Tasks With The Husband. She Takes These Responsibilities On Her Own. (Jaffe, Berger, 1994; Acevedo Et All, 2004)

- $\quad$ Physically Perfect: This Portrayal Is Related To The Imposition Of A Particular Image, That Is, Always Slim, Beautiful And Young. (Acevedo Et All, 2004)

- Caucasian Ethnic Characteristics: Woman Is Depicted As Belonging To The Caucasian Ethnic Group. (Acevedo Et All, 2004)

- Independent: Woman Is Viewed As Being Financially Or Psychologically Independent From Men. (Kang, 1997; Acevedo Et All, 2004)

- Home And Family Tasks Equity: Woman And Man Share The Family And Home Responsibilities. (Jaffe, Berger, 1994)

- $\quad$ Not Caucasian Ethnic Characteristics: Women With Features Of Non Caucasian Groups (Developed In The Pre-Test Of This Study)

- $\quad$ Function Equity: When A Man And A Woman Collaborate Face To Face And They Are Likely To Perform Equal Roles. There Is No Hierarchy Of Function. This Function Equality Is Pictured Either Within An Occupational Frame Or Outside Of Occupational Specialization (Developed In The Pre-Test Of This Study)

- $\quad$ Rational: Refers To The Image Of Women Who Use There Intelligence Or Base Their Behavior In A Rational Thinking Process (Developed In The Pre-Test Of This Study)

- Women As Prestigious Or Professional Or High Income Earner: Refers To Women In A Prestigious Position, In A High Wage Position Or In A High Educated Position. Examples Are: Judges, Professors, Executives, Medical Doctors, Dentists, Scientists (Developed In The Pre-Test Of This Study).

\section{Operational Rules}

The operational rules for each category were taken from previous research, and were formulated as follow:

Feminine touch:

- Using hands or fingers to trace the objects outlines, to hold it in a protective manner or to caress it or just to touch it.

- $\quad$ Function ranking:

- $\quad$ Man teaching woman

- Woman serving man

- Man in a hierarchical superior function in relation to woman

- Man determines what it is supposed to be done.

- $\quad$ Ritualization of Subordination

- $\quad$ Lowering oneself physically

- $\quad$ Knee bend

- $\quad$ Body or head leant

- $\quad$ Lying or sitting on the bed or floor

- $\quad$ Licensed Withdraw

- Hand covering mouth or face

- $\quad$ Head or eye gaze aversion

- $\quad$ Maintaining telephone conversation or reading

- $\quad$ Body-Revealing Clothes or nudity 
- $\quad$ Female model wearing body revealing clothes (mini skirts, tide skirts, shorts, transparent clothing, bath clothing) or showing nudity (wearing underwear, rolled up in towels, without clothes)

- $\quad$ Dependent

- $\quad$ Financially dependent from men: she doesn't show to be able to earn money alone to maintain herself. She doesn't have an income or a job. She depends on man's earnings to live.

- $\quad$ Psychologically dependent from men: in order to complete a task she needs male instruction; she needs male encouragement or reinforcement; she doesn't take decisions alone; she doesn't have the initiative for doing things. She needs a man to take care of her

- Housewife

- Woman concerned or engaged in house activities or is concerned with cleanliness

- Women concerned with being a good housewife

- $\quad$ Decorative roles

- Woman has no relation to the product. Although, she is in the foreground of the scene, she performs no function.

- Woman has no relation to the product and performs no function. She is presented in the end of the ad, or she is shown quite quickly. In addition, she is in the background of the scene.

- Women as physically beautiful

- Woman concerned with cosmetic products or with extraneous accessories to enhance physical beauty

- $\quad$ Woman concerned with looking more youthful, slimmer, more appealing

- Women as shallow

- Woman is primary concerned with: luxury leisure, expensive adornments, material possessions; spending money; amusing herself

- Irrational

- Woman makes decisions that are incoherent. Or she is not able to offer solutions in difficult or unexpected situations.

- Window display

- Woman exhibits the product in her body, as her body was a hanger or a shelf for the product

- $\quad$ An object of ridicule

- The woman is the center of a joke or comments with sexual or malicious connotations; she plays the role of ridiculously comic.

- Women as low income earners

- Woman performing intermediate level position job. This intermediate level is related to degrees of education. Examples: clerical or secretarial positions.

- $\quad$ Woman as blue or pink collar worker

- $\quad$ Superwoman

- Woman performs many roles at the same time. She has an occupational role; she is housewife, mother and wife. However, she takes care of the home and family tasks alone. She doesn't share these activities with the husband.

- $\quad$ Physically perfect

- Woman as young, beautiful and slim

- Caucasian ethnic characteristics

- Woman presents Caucasian characteristics: fair hair, fair eyes, and fair skin

- Independent

- Woman as financially independent from man. She has a job and earns wage with which she maintains herself.

- Woman as psychologically independent from man. She completes tasks alone; she doesn't need male encouragement or reinforcement; she takes decisions alone; she takes the initiative for doing things. She doesn't need a man to take care of her

- $\quad$ Home and family tasks equity

- $\quad$ Man and woman shares responsibilities in family and home activities

- Not Caucasian ethnic characteristics 
- Woman presents Non-Caucasian physical characteristics: as dark hair, dark eyes, and dark skin. Or she presents mulata, black, Asian, Arabian, or Latin physical characteristics.

- $\quad$ Function equity

- $\quad$ Woman and man play equivalent occupational roles positions

- $\quad$ Either woman or man determine what it should be done (the equally of function is pictured either within an occupational frame or outside of occupation specializations)

- Rational

- Woman makes decisions that are coherent; she offers solutions in difficult or unexpected situations

- Women in a prestigious or professional or high income earner

- Woman as high level professionals. These occupational positions are related to high wages, social prestige and high level of education

All the categories and their measurements were pre-tested by one graduate student and two professors of marketing. The three of them worked separately. When the definitions of the categories or their measurements were not clear, that is, when doubts emerged, the definitions were rewritten until they had become clear. Thus, the investigation procedures conform to content analysis conditions of pre-testing the categories and measurements.

Six graduate students were used to code the pieces of advertisements selected. There was a training period in which the coders analyzed a set of sample and learned how to work on them. In addition, this study employed an independent judge process, which means that coders were able to report autonomous assessments without inputs from the researchers or other arbiter, because each evaluator worked alone and the authors did not compose the appraiser team. Thus, the requirements of judge independence and judge training were followed.

Reliability - Interjudge Reliability Is The Rate Of Agreement Between The Coders Who Are Applying The Same Set Of Categories To The Same Content. Hence, It Is The Degree Of Consistency Between Judges. High Levels Of Disagreement Among Them Indicate A Flaw In Research Methods. The Most Often Reliability Index Used By Previous Research Is The Coefficient Of Agreement Which Is Composed By The Total Number Of Agreements Divided By The Total Number Of Coding Decisions. If More Than Two Judges Are Engaged, The Typical Number Provided Is The Percentage Of Agreement Between Each Pair Of Judges (Kolbe; Burnett, 1991; Karsarjian, 1977). Berelson (1952) States That The Reliability Index Should Range Between 66\% And 95\% However, According To Kassarjian (2001) This Coefficient Should Be Above 85\%.

In this study the index applied was the coefficient of agreement. In addition, as we have used six judges the figure provided is the percentage of agreement between each pair of judges. The interjudge reliability index was examined to verify whether the categories and their rules did not contain any bias. Indeed, in this study these coefficients can be considered high. The lower figure was $87,5 \%$, between rater 1 and 3 . Actually, the reliability coefficients ranged from $87,5 \%$ to $92,4 \%$. These figures indicate that there is a high degree of consistency between the judges. These indexes are presented in table 2:

Table 2

\begin{tabular}{|c|c|c|c|c|c|c|}
\hline Judge & 1 & 2 & 3 & 4 & 5 & 6 \\
\hline 1 & $\mathrm{X}$ & $90,9 \%$ & $87,5 \%$ & $90,8 \%$ & $88,6 \%$ & $89,8 \%$ \\
\hline 2 & & $\mathrm{X}$ & $91,2 \%$ & $92,4 \%$ & $90,9 \%$ & $91,4 \%$ \\
\hline 3 & & & $\mathrm{X}$ & $89,9 \%$ & $90,1 \%$ & $90,9 \%$ \\
\hline 4 & & & & $\mathrm{X}$ & $90,8 \%$ & $91,0 \%$ \\
\hline 5 & & & & & $\mathrm{X}$ & $89,9 \%$ \\
\hline 6 & & & & & & $\mathrm{X}$ \\
\hline
\end{tabular}




\section{RESULTS}

Frequencies of roles portrayed by women in advertisements examined are presented in table 3.

Table 3: Frequency Of Female Portrayals In Advertisements

\begin{tabular}{|c|c|c|c|c|}
\hline Decades & $1973-1980$ & 1981-1990 & $1991-2000$ & $1973-2000$ \\
\hline \multicolumn{5}{|l|}{ Stereotyped portrayals } \\
\hline Feminine touch & $5,3 \%$ & $6,1 \%$ & $0,5 \%$ & $1,2 \%$ \\
\hline Function ranking & $21,3 \%$ & $8,3 \%$ & $4,2 \%$ & $3,0 \%$ \\
\hline Ritualization of subordination & $24 \%$ & $11,8 \%$ & $5,7 \%$ & $3,8 \%$ \\
\hline Licensed withdraw & $14 \%$ & $1,8 \%$ & $2,1 \%$ & $1,5 \%$ \\
\hline Body-Revealing clothes or Nudity & $21,3 \%$ & $38,2 \%$ & $37,5 \%$ & $9,8 \%$ \\
\hline Dependent & $29,3 \%$ & $12,3 \%$ & $18,2 \%$ & $5,5 \%$ \\
\hline Housewife & $19,3 \%$ & $11,0 \%$ & $19,3 \%$ & $4,7 \%$ \\
\hline Decorative role & $18,0 \%$ & $21,5 \%$ & $30,2 \%$ & $6,9 \%$ \\
\hline Women as physically beautiful & $9,3 \%$ & $11,0 \%$ & $10,4 \%$ & $3,0 \%$ \\
\hline Women as shallow & $9,3 \%$ & $3,5 \%$ & $6,8 \%$ & $1,8 \%$ \\
\hline Irrational & $10,0 \%$ & $6,6 \%$ & $10,4 \%$ & $2,6 \%$ \\
\hline Window display & $16,7 \%$ & $26,8 \%$ & $12,0 \%$ & $5,6 \%$ \\
\hline An object of ridicule & $11,3 \%$ & $14,9 \%$ & $20,8 \%$ & $4,7 \%$ \\
\hline Women as low income earners & $2,7 \%$ & $5,3 \%$ & $2,1 \%$ & $1,0 \%$ \\
\hline Super woman & $0,7 \%$ & $1,8 \%$ & $1,0 \%$ & $0,4 \%$ \\
\hline \multicolumn{5}{|l|}{ Idealized portrayals } \\
\hline Physically perfect & $41,3 \%$ & $53,5 \%$ & $49,5 \%$ & $14,4 \%$ \\
\hline Caucasian ethnic characteristics & $19,3 \%$ & $22,4 \%$ & $33,3 \%$ & $7,4 \%$ \\
\hline \multicolumn{5}{|l|}{ Plural portrayals } \\
\hline Independence & $15,3 \%$ & $23,7 \%$ & $12,5 \%$ & 5,2 \\
\hline Home and family tasks equity & $0,0 \%$ & $1,3 \%$ & $1,0 \%$ & $0,3 \%$ \\
\hline Not Caucasian ethnic characteristics & $45,3 \%$ & $46,5 \%$ & $40,6 \%$ & $13,0 \%$ \\
\hline Function equity & $5,3 \%$ & $7,5 \%$ & $3,1 \%$ & $1,6 \%$ \\
\hline Rational & $5,3 \%$ & $8,8 \%$ & $7,3 \%$ & $2,2 \%$ \\
\hline $\begin{array}{l}\text { Women in a prestigious or professional } \\
\text { or high income earners }\end{array}$ & $1,3 \%$ & $2,2 \%$ & $0,0 \%$ & 0,4 \\
\hline Number of classifications & 150 & 228 & 192 & 1940 \\
\hline Number of ads analyzed in the period & 25 & 39 & 31 & 95 \\
\hline
\end{tabular}

Overall, a longitudinal analysis of the presence of these images through the three different decades shows that they have followed different trends. The findings by the three groups of portrayals, stereotyped, idealized and plural, are as follow:

\section{Stereotyped Portrayals}

First of all, the following pictures "Function ranking", Ritualization of subordination, Licensed withdraw, Dependent, Women as shallow declined in later years in comparison to former years. Images as Feminine touch and Window display maintained or increased its performances in the second decade (1981-1990) in comparison to the first one (1973-1980), however, they presented a strong decrease in the last term (1991-2000).

Descriptions as "Body revealing clothes or nudity", "Decorative roles", "An object of ridicule have increased in later years in comparison to former years. On the other hand, images as Women as low income earners and Super women have rarely been shown through the 27 years term. Moreover, some stereotyped portrayals as Women as physically beautiful, Housewife and Irrational did not play an extremely significant position among other images; however, they were presented in ads in a regular basis during the extent of time under analysis. 


\section{Idealized Portrayals}

The two idealized depictions were always well represented through the three decades of the investigation. Indeed, in comparison to the other portrayals in the study, the image "physically perfect" was one of the two which were most depicted. In addition, the pictures "Caucasian ethnic characteristics" and "Physically perfect" have increased in later years in comparison to former years.

\section{Plural Portrayals}

In relation to the plural portrayals, two of them appeared most often during the 27 years under analysis. They were: Not Caucasian ethnic characteristics and Independence. Indeed, the first one was the picture most exhibited in the 27 year-period of investigation. These two pictures maintained or increased its performances in the second decade (1981-1990) in comparison to the first term (1973-1980). However, they presented a strong decrease in the last term (1991-2000). On the other hand, the pictures as "Home and family tasks equity" and "Women in a prestigious or professional or high income earners" have rarely been shown through the 27 years term.

A summary of these results is presented in table 4.

Table 4 - Summary of the results

\section{STEREOTYPED PORTRAYALS}

SIGNIFICANTLY REPRESENTED THROUGH THE THREE DECADES

Body revealing clothes or nudity, dependent, housewife, decorative roles, women as physically beautiful, irrational, window display, object of ridicule

STRONGLY REPRESENTED IN THE FIRST DECADE, DECLINING FROM THE SECOND DECADE

Function ranking; Ritualization of subordination; Licensed withdraw; Women as shallow

PORTRAYALS WHICH HAVE DECLINED IN LATER YEARS

Function ranking; Ritualization of subordination; Licensed withdraw; Dependent; Women as shallow

Feminine touch; Window display

PORTRAYALS WHICH HAVE INCREASED IN LATER YEARS

Body revealing clothes or nudity; Decorative roles; An object of ridicule

PORTRAYALS RARELY SHOWN THROUGH THE 27 YEARS

Women as low income earners; Super women

PRESENTED IN ADS IN A REGULAR BASIS THROUGH THE 27 YEARS

Women as Physically beautiful; Housewife; Irrational

IDEALIZED PORTRAYALS

SIGNIFICANTLY REPRESENTED THROUGH THE THREE DECADES

Physically perfect

Caucasian ethnic characteristics

PORTRAYALS WHICH HAVE DECLINED IN LATER YEARS

Not Caucasian ethnic characteristics

PORTRAYALS WHICH HAVE INCREASED IN LATER YEARS

Caucasian ethnic characteristics; physically perfect

THE PLURAL PORTRAYALS

SIGNIFICANTLY REPRESENTED THROUGH THE THREE DECADES

Independence-P

Not Caucasian ethnic characteristics

PORTRAYALS WHICH HAVE DECLINED IN LATER YEARS

Independence

PORTRAYALS RARELY SHOWN THROUGH THE 27 YEARS

Home and family tasks equity; Women in prestigious or professional or high income earners 


\section{DISCUSSION}

The Discussion Of This Paper Was Structured Having In Mind The Following Questions: 1) Which Is The Meaning Of Our Results? 2) How Similar Or How Different Are These Results In Comparison With Previous Research? Or, How Can We Connect These Conclusions To Previous Investigations And To Our Literature Review?

First Of All, These Results Mean That Advertisements Have Been Idealizing Female Images Over The Years. Also, They Show That Stereotyped Imagery Was Always Present In Publicity. While Some Types Of Depreciated Images Have Declined, Others Have Increased.

In Comparison To Previous Research Part Of Our Data Shows The Same Patterns Of Images. Specifically, Previous Studies Have Found That Female Portrayals Are Shown In A Stereotyped Way. We Also Have Found This Trend. More Specifically, Part Of Our Results Is Consistent With Goffman'S (1979), Kang'S (1997), Belkaoui; Belkaoui’S (1976), Acevedo Et Al (2004), Courtney; Lockeretz (1971) And Venkatesan; Losco (1975).

A Comparison Of This Investigation With Kang'S Study (1997) Shows That We Found Some Of The Same Patterns. In Kang'S Research The Portrayal Of "Function Ranking" Also Dropped Over The Years. Moreover, The Image Of "Body Revealing Clothes Or Nudity", Named By Him As "Body-Display", Raised Its Representation Over The Decades In Both Studies. However, In The Present Research, "Ritualization Of Subordination" And "Licensed Withdrawal" Declined. In His Analysis These Two Portrayals Increased Its Participation From 1979 To 1991.

Part Of Our Results Is Consistent With Previous Studies. For Example: Courtney And Lockeretz (1971) Found That Advertising Depicts Women As Being Dependent From Men. Venkatesan; Losco (1975) Findings Showed That Women Were Pictured As: Physically Beautiful, As Housewife, And Dependent On Men. Furthermore, Belkaoui; Belkaoui'S Conclusions (1976) Indicate That Women Were Depicted Primary In Decorative Roles. These Portrayals Have Also Emerged In The Present Research.

In Addition, As Previous Studies Have Shown (Belkaoui; Belkaoui, 1976 For Example) This Investigation Reveals That Some Portrayals Which Represent Women In Equalitarian Roles In Comparison To Men Are Rarely Represented In Publicity. On The Other Hand, Acevedo Et All (2004) Found That Women Interviewed In Their Study Perceived That Advertising Depicts Females As: "Not Intelligent Or Irrational"; "Window-Display"; "Body Display" (Labeled In The Present Study As Body Revealing Clothes Or Nudity); As "Housewives"; "Physically Perfect", And With "Caucasian Ethnic Characteristics". These Pictures Have Also Emerged From Our Results. Further, Previous Studies Also Have Described That Women Are Depicted In An Idealized Manner. Rocha (1984), For Example, Stresses The Magic And Perfect Aspect Of Advertising Imagery. Our Results Show That Idealized Portrayals Are Strongly Represented In Mass Media.

However, What Is New In Our Investigation Is That Our Data Have Indicate That Some Plural Portrayals, As "Independence" And "Not Caucasian Ethnic Characteristics" Were Always There, As They Are Significantly Represented In The 1973-1980 Term. In Addition, Some Stereotyped Categories Mentioned In The Literature Were Rarely Represented In The Ads Of This Study, As Super Women (Acevedo Et All, 2004), "Women As Low Income Earners" (Belkaoui; Belkaoui, 1976) And "Feminine Touch" (Kang, 1997 And Goffman, 1979).

In Freyre'S Descriptions (2003) About Women In The Patriarchal Society, Some Issues Are Outstanding, Such As: The Association Of Women To The Domestic Dimension Of Life, The Role Of Mother And Housekeeper And The Idealization Of The Body. Indeed, These Themes, In Some Way, Have Also Emerged From Our Results. For Example, The Housekeeper And Mother's Roles Are Related To The "Housewife" Category. On The Other Hand, The Idealization Of The Body Described By Freyre (2003) Is Related To The "Physically Perfect" Portrayal. In This Depiction The Central Points Are Beauty And perfectionism. Moreover, Freyre's descriptions (2003) denounce how prejudice was the patriarchal society against women. She was considered the "fragile sex" and the "fleshly puppet". Also, she was confined to artificial situations to provide pleasure to male. Besides, gender relations were dominated by men and they were molded in order to satisfy their narcissistic satisfaction. In this way, our results reveal portrayals 
(the stereotyped and idealized ones) which are impregnated by prejudice against women and insinuate a hidden trace of male domination.

\section{CONCLUSION}

The main objective of this research was to examine female roles portrayed by advertising. More specifically, we wanted to understand what messages about women have been given to society through advertising and whether these portrayals have been changed during the past decades.

We understand that messages that advertising have given to society are that women are not considered equally to men.. In addition, we interpret that in Brazilian society there are many stereotypes against women and their images are used in to give pleasure to men. Furthermore, prejudices which have roots in the patriarchal regime are still impregnated in social relations in this country. Additionally, women still occupy positions that are inferior to men. Overall, female portrayals have changed over the years. However, they continued to be idealized and stereotyped.

According to Sabat (2001) when publicity employs a specific image this means that this speech already exists in society. Hence, we can interpret that the categories which were most represented in this study reflect society gender relations and female roles.

Some implications to managers and publicity professionals can be drawn from this investigation. First of all, advertisers should be alert that women would like to be shown in the roles they are used to playing in society. Those professionals who choose to portray female images in a more realistic manner might benefit from their consumption. As to any research, this study has limitations that also suggest possibilities for future investigative endeavor. For instance, future research could use another technique approach to explore the same subject. Moreover, these results suggest the need for more research in female content analysis. Other studies in the area would be useful. In addition, some of the constructs and operational rules proposed in this investigation should be reanalyzed and tested.

\section{REFERENCES}

1. Acevedo Et All. Social Representations Of Women In Advertising Images. In: Encontro Anual Da Associação Dos Programas De Pós-Graduação Em Administração, $28^{\circ}$ Enanpad, 2004. Curitiba, Anais ... Rio De Janeiro: Anpad, 2004.

2. $\quad$ Belk; R.; Pollay, R. Images Of Ourselves: The Good Life In Twentieth Century Advertising. Journal Of Consumer Research. V. 11, P. 887-897, March. 1985

3. Belkaoui, A., Belkaoui, J. A Comparative Analysis Of The Roles Portrayed By Women In Print Advertisements: 1958, 1970, 1972. Journal Of Marketing Research, Vol. Xiii, P. 168-172, May 1976.

4. Berelson, B. Content Analysis In Communication Research. New York: Macmillan, 1952. 220p.

5. Blackwood, R. The Content Of News Photos: Roles Portrayed By Men And Women. Journalism Quarterly, 60, No. 1 P. 710-14, 1983.

6. Bretl, D.; Cantor, J. The Portrayal Of Men And Women In U.S. Television Commercials: A Recent Content Analysis And Trends Over15 Years. Sex Roles, 18, No. 9/10, P. 595-609, 1988.

7. Courtney, A. Lockeretz, S. A Woman's Place: An Analysis Of The Roles Portrayed By Women In Magazine Advertisements. Journal Of Marketing Research, No.8, P. 92-95, Feb. 1971.

8. Freyre, G. Sobrados E Mucambos. 14 Ed. São Paulo: Global, 2003. 968p. ISBN 85-260-0835-8.

9. Goethals, G. Social Comparison Theory: Psychology From The Lost And Found. Personality And Social Psychology Bulletin, 12, P. 261-278, Sep. 1986.

10. Goffman, E. Gender Advertisements. Cambridge: Harvard University Press, 1978.

11. Gulas. C.; Mckeage, K Extending Social Comparison: An Examination Of The Unintended Consequences Of Idealized Advertising Imagery. Journal Of Advertising. Provo, V.29 N. 2, P. 17-28, Summer 2000.

12. Holsti, O. R. Content Analysis For The Social Sciences And Humanities, Reading, Ma: Addison-Wesley, 1969.

13. Jaffe, L. Berger, P. The Effect Of Modern Female Sex Role Portrayals On Advertising Effectiveness. Journal Of Advertising Research. New York, V.34 N. 4 P.32-50, Jul.-Aug.1994. 
14. Jolliffe, L. Comparing Gender Differentiation In The New York Times, 1885 And 1985. Journalism Quarterly, 62, N.1, P. 683-91, 1989.

15. Kang, Mee-Eun. The Portrayal Of Women's Images In Magazine Advertisements: Goffman's Gender Analysis Revisited. Sex Roles, New York, V. 37, N. 11/12, P. 979-997, Dec. 1997.

16. Kassarjian, H. Content Analysis In Consumer Research. Journal Of Consumer Research, V. 4, Issue, 1, P. 818, Jun. 1977.

17. Kolbe, R. H.; Burnett, M. Content Analysis Research: An Examination Of Applications With Directives For Improving Research Reliability And Objectivity. Journal Of Consumer Research, V. 18, N. 2, P. 243-248, Sept. 1991.

18. Kosimar, L. Woman In Sexist Society. New York: Basic, 1971.

19. Lennon, S.; Lillethun, A.; Buckland, S. Attitudes Toward Social Comparison As A Function Self-Esteem: Idealized Appearance And Body Image. Family And Consumer Sciences Research Journal, V.27 N. 4 P. 379-405, Jun 1999.

20. Luebke, B. Out Of Focus: Images Of Women And Men In Newspaper Photographs. Sex Roles, V.20, N. 3/4, P.121-33, 1989.

21. Martin, M., Kennedy, P. Advertising And Social Comparison: Consequences For Female Preadolescents And Adolescents, Psychology \& Marketing, V. 10 N. 6, P. 513-530, 1993.

22. Martin, M.; Gentry, J. Stuck In The Model Trap: The Effects Of Beautiful Models In Ads On Female PreAdolescents And Adolescents. Journal Of Advertising, V. 26, N.2, P.19-33, Summer 1997.

23. Richins, M., Social Comparison And The Idealized Images Of Advertising, Journal Of Consumer Research, 18, P. 71-83, June 1991.

24. Rocha, E. Magia E Capitalismo. 3 Ed. São Paulo: Brasiliense, 1995. 162 P. ISBN 85-11-07016-8

25. Sabat, R. Pedagogia Cultural, Gênero E Sexualidade. Estudos Feministas. São Paulo, V. 11, Ano 9, P.9-21, 2o Semester 2001.

26. Stephens, D., Hill, R., Hanson, C. The Beauty Myth E Female Consumers: The Controversial Role Of Advertising. The Journal Of Consumer Affairs, P. 137-149, Summer 1994.

27. Stice, E., Shaw, H. Adverse Effects Of The Media Portrayed Thin-Ideal On Women And Linkages To Bulimic Symptomatology. Journal Of Social And Clinical Psychology, V.13, P.288-308. 1994.

28. Strauss, A.; Corbin, J. (1990), Basics Of Qualitative Research, London: Sage, 1990.

29. Thornton, B., Maurice, J. Physical Attractiveness Contrast Effect And The Moderating Influence Of SelfConsciousness. Sex Roles, Volume: 40 No. 5/6 P.379-392, Mar 1999.

30. Venkatesan, M., Losco, J. Women In Magazine Ads: 1959-71. Journal Of Advertising Research, Vol. 15, No. 5, P. 49-54. Oct.1975.

31. Williamson, J. Decoding Advertisements: Ideology And Meaning In Advertising. London: Marion Bayars. 1978. 


\section{NOTES}

